\title{
PENGGUNAAN MODEL POE2WE DALAM PEMBELAJARAN FISIKA MATERI TERMODINAMIKA DENGAN BANTUAN PhET (PHYSICS EDUCATION TECHNOLOGY) SIMULATION
}

\author{
Ahmad Toni Pratama ${ }^{1}$ Nana $^{2}$ \\ ${ }^{1}$ Mahasiswa Program Studi Pendidikan Fisika, Universitas Siliwangi \\ ${ }^{2}$ Dosen Program Studi Pendidikan Fisika, Universtias Siliwangi \\ Universitas Siliwangi Tasikmalaya \\ *Email: ahmadtonipratama@gmail.com
}

\begin{abstract}
The purpose of this paper is to determine the use of the POE2WE model in the study of physics using thermodynamic material with the help of PhET. The background of this writing is that for thermodynamic material it is rare to carry out experiments (practicum) and the concepts of thermodynamics are abstract material, difficult to visualize and have quite high complexity. Therefore the use of the PhET-assisted POE2WE model is an alternative for conducting experiments in the form of virtual experiments. The method used in this article is literature study. Data from the literature is collected and analyzed to be presented in the results and discussion to draw conclusions. The writing results point out that the PhET-assisted POE2WE model can be applied in thermodynamic learning as an alternative to virtual experiments.
\end{abstract}

Keywords: POE2WE, PhET, Thermodynamics, Virtual Experiments

ABSTRAK: Tujuan penulisan ini adalah untuk mengetahui penggunaan model POE2WE dalam pembelajran fisika materi termodinamika menggunakan dengan bantuan PhET. Latar belakang penulisan ini yaitu untuk materi termodinamika jarang sekali untuk melaksanakan eksperimen (praktikum) dan konsep-konsep termodinamika merupakan materi yang abstrak, sulit untuk divisualisasikan dan memiliki kompleksitas yang cukup tinggi. Maka dari itu penggunaan model POE2WE berbantuan PhET menjadi alternative untuk melakukan eksperimen berupa eksperimen virtual. Metode yang digunakan dalam artikel ini adalah studi pustaka. Data dari literature dikumpulkan dan dianalisis untuk disajikan dalam hasil dan diskusi untuk menarik kesimpulan. Hasil penulisan menujukan bahwa model POE2WE berbantuan PhET dapat diterapkan dalam pembelajaran termodinamika sebagai alternatif berupa eksperimen virtual.

Kata Kunci : POE2WE, PhET, Termodinamika, Eksperimen Virtual

\section{PENDAHULUAN}

Pembelajaran kurikulum 2013 adalah pembelajaran kompetensi dengan memperkuat proses pembelajaran dan penilaian autentik untuk mencapai kompetensi sikap, pengetahuan, dan keterampilan. Penguatan proses pembelajaran dilakukan melalui pendekatan saintifik, yaitu pembelajaran yang mendorong siswa lebih mampu dalam mengamati menanya mencoba/mengumpulkan data, mengasosiasi/menalar, dan mengomunikasikan (Nana, Sajidan, Akhyar, \& Rochsantiningsih).

Model pembelajaran Prediction, Observation, Explanation, Elaboration, Write and Evaluation (POE2WE) dikembangkan dari model pembelajaran POEW dan model pembelajaran Fisika dengan Pendekatan Konstruktivistik. Model POE2WE merupakan model pembelajaran yang dikembangkan untuk mengetahui pemahaman siswa mengenai suatu konsep dengan pendekatan konstruktivistik. Model ini membangun pengetahuan dengan urutan proses terlebih dahulu meramalkan atau memprediksi solusi dari permasalahan, melakukan eksperimen untuk membuktikan prediksi, kemudian menjelaskan hasil eksperimen yang diperoleh secara lisan maupun tertulis, membuat contoh penerapan dalam kehidupan 
sehari-hari, menuliskan hasil diskusi dan membuat evaluasi tentang pemahaman siswa baik secara lisan maupun tertulis (Nana, 2018)

Bagi sebagian siswa pelajaran fisika masih di anggap sulit. Dalam pembelajaran di sekolah jarang diajarkan tentang contoh penerapan dalam kehidupan sehari-hari, sehingga siswa merasa fisika merupakan pelajaran yang tidak bermanfaat setelah lulus nantinya (Sari dkk., 2013). Menurut Aprianti dkk (2015), pendidikan yang dijalankan selama ini masih memisahkan pengetahuan formal siswa dengan pengalaman sehari-hari siswa. Sehingga kemampuan siswa untuk mengaitkan konsep fisika dalam kehidupan seharihari masih kurang. Selain itu, salah satu penyebab lain kesulitan siswa mempelajari fisika adalah bahan ajar yang digunakan. Sumber belajar berupa buku teks terbatas dan kurang menarik untuk dibaca atau ditelusuri oleh siswa (Tampubolon dkk., 2015).

Tujuan dalam pembelajaran fisika mencakup aspek pemahaman dan penerapan konsep serta pelatihan dan pengembangan kinerja ilmiah (Jihad, 2008). Pemahaman konsep dan penerapan konsep fisika didapat siswa dari sumber-sumber pembelajaran seperti buku bacaan, informasi guru dan media pembelajaran. Sedangkan pelatihan dan pengembangan kinerja ilmiah didapat siswa dari kegiatan praktikum (eksperimen), praktikum memang penting untuk melatih keterampilan proses, karena sains terbentuk dan berkembang melalui suatu proses ilmiah. Oleh karena itu, sesuai dengan yang tercantum pada Permendiknas No. 41 tahun 2007, maka dalam pelaksanaan pembelajaran seharusnya guru memfasilitasi peserta didik melakukan percobaan di laboratorium. Dengan demikian yang perlu diperhatikan guru adalah bagaimana cara mengorganisasi pembelajaran, cara menyampaikan isi pembelajaran, dan bagaimana cara menata interaksi antara sumber-sumber belajar yang ada agar dapat berfungsi secara optimal untuk mencapai tujuan-tujuan pembelajaran tersebut (Fathul Mubarok, 2014).

PhET merupakan ciptaan dari komunitas sains melalui PhET Project di Univercity of Colorado, USA.

PhET (Physics Education Technology) merupakan sebuah situs yang mnyediakan simulasi pembelajaran fisika yang dapat di download secara gratis untuk kepentingan pengajaran di kelas atau dapat digunakan untuk kepentingan belajar individu. Adapun kelebihan dari PhET ini yaitu media interaktif yang sangat menarik karena sangat asyik, mudah dan menyenangkan. Sedangkan kekurangannya yaitu keberhasilan pembelajaran bergantung pada kemandirian siswa untuk mengikuti proses pembelajaran. Dengan menggunakan media PhET Simulations diharapkan siswa mampu dan dapat menerapkan konsep yang telah diperoleh selama pembelajaran secara teori dan praktikum ke simulasi yang terdapat dalam media PhET tersebut salah satunya pada materi Termodinamika.

Dalam materi Termodinamika untuk melakukan eksperimen langsung sangat lah sulit dibutuhkan alat-alat yang canggih dan laboratorium yang memadai. Agar materi termodinamika tersampaikan sebagai pemahaman konsep maka untuk percobaan termodinamika menggunakan laboratorium virtual dengan

menggunakan PhET Colorado. Berdasarakan latar belakang tersebut, maka disusunlah penelitan yang berjudul "PENGGUNAAN MODEL POE2WE DALAM PEMBELAJARAN FISIKA MATERI TERMODINAMIKA DENGAN BANTUAN PhET (PHYSICS EDUCATION TECHNOLOGY) SIMULATION DI ABAD 21”

\section{METODE PENELITIAN}

Metode yang digunakan dalam artikel ini adalah studi literature atau studi pustaka. Data dikumpulkan dan dianalisis disajikan dalam hasil dan pembahasan untuk menarik kesimpulan. 


\section{HASIL DAN PEMBAHASAN}

\subsection{Model POE2WE}

Model pembelajaran Prediction, Observation, Explanation, Elaboration, Write dan Evaluation (POE2WE) dikembangkan dari model pembelajaran POEW dan model pembelajaran Fisika dengan Pendekatan Konstruktivistik. Pengembangan ini dilakukan untuk sebagai penyempurnaan kedua model sebelumnya. Model POE2WE merupakan model pembelajaran yang dikembangkan untuk mengetahui pemahaman peserta didik mengenai suatu konsep dengan pendekatan konstruktivistik. Model ini membangun pengetahuan dengan urutan proses yaitu meramalkan atau memprediksi solusi dari permasalahan, melakukan eksperimen untuk membuktikan prediksi, kemudian menjelaskan hasil eksperimen yang diperoleh secara lisan maupun tertulis, membuat contoh penerapan dalam kehidupan sehari-hari, menuliskan hasil diskusi dan memuat evaluasi tentang pemahaman peserta didik baik secara lisan maupun tertulis (Nana et al., 2014; 2016).

Model pembelajaran POE2WE dapat menjadikan peserta didik sebagai subjek di dalam pembelajaran. peserta didik secara aktif menemukan suatu konsep melalui pengamatan atau eksperimen secara langsung, bukan dari menghafal buku materi maupun penjelasan dari guru. Model ini memungkinkan peserta didik aktif dalam proses pembelajaran, memberikan kesempatan kepada peserta didik untuk konstruktivistik pengetahuannya, mengkomunikasikan pemikirannya dan menuliskan hasil diskusinya sehingga peserta didik lebih menguasai dan memahami konsep yang akan berdampak pada peningkatan prestasi belajar peserta didik Model ini memberikan kesempatan kepada peserta didik untuk melakukan konstruksi pengetahuan yang dimilikinya, melakukan pengamatan terhadap fenomena serta mengkomunikasikan gagasan yang dia perolah dari proses diskusi sehingga peserta didik akan lebih mudah menguasai konsep yang diajarkan (Nana, 2014,2016; Nana et al., 2014; Nana dan Surahman, 2019, 2020; Permatasari, 2011; Rahayu et al., 2013; Samosir, 2010).

Penggabungan tahapan-tahapan pembelajaran model POEW dan model pembelajaran Fisika dengan Pendekatan Konstruktivistik maka dapat di susun langkah-langkah pembelajaran model POE2WE secara terinci sebagai berikut (Nana dan Surahman, 2019; 2020):

a) Prediction

Tahap prediction yaitu peserta didik membuat prediksi atau dugaan awal terhadap suatu permasalahan. Permasalahan yang ditemukan berasal dari pertanyaan dan gambar tentang materi yang disampaikan oleh guru yang ada di Lembar Kerja peserta didik (LKS)/bukupeserta didik sebelum peserta didik membuat prediksi. Pembuatan prediksi jawaban tahap Prediction pada model POEW identik dengan fase Engagenent pada pendekatan konstruktivistik. Guru mengajukan pertanyaan yang dapat mendorong peserta didik untuk dapat membuat prediksi atau jawaban sementara dari suatu permasalahan.

b) Observation

Tahap Observation yaitu untuk membuktikan prediksi yang telah di buat oleh peserta didik. Peserta didik diajak melakukan eksperimen berkaitan dengan masalah atau persoalan yang di temukan. Selanjutnya peserta didik mengamati apa yang terjadi, kemudian peserta didik menguji kebenaran dari dugaan sementara yang telah dibuat. Tahap Observation pada model POEW identik dengan fase Exploration pada pendekatan konstruktivistik.

c) Explanation

Tahap Explanation atau menjelaskan yaitu peserta didik memberikan penjelasan terhadap hasil eksperimen yang telah dilakukan. Penjelasan dari peserta didik dilakukan melalui diskusi dengan anggota kelompok kemudian tiap kelompok mempresentasikan hasil diskusinya di depan 
kelas. Jika prediksi yang di buat peserta didik ternyata terjadi di dalam eksperimen, maka guru membimbing peserta didik merangkum dan memberi penjelasan untuk menguatkan hasil eksperimen yang dilakukan. Namun jika prediksi peserta didik tidak terjadi dalam eksperimen, maka guru membantu peserta didik mencari penjelasan mengapa prediksi atau dugaannya tidak benar. Tahap explanation identik dengan fase explanation pada pendekatan konstuktivistik.

d) Elaboration

Tahap elaboration yaitu peserta didik membuat contoh atau menerapkan konsep dalam kehidupan sehari-hari. Tahap elaboration di ambil dari pendekatan konstruktivistik. Tahap ini guru medorong peserta didik untuk menerapkan konsep baru dalam situasi baru sehingga peserta didik lebih memahami konsep yang di ajarkan guru. Tahap ini pengembangan dari pendekatan konstruktivistik.

e) Write

Tahap write atau menulis yaitu melakukan komunikasi secara tertulis, merefleksikan pengetahuan dan gagasan yang dimiliki peserta didik Menurut Masingilia dan Wisniowska (1996) dalam (Yamin \& Ansari, 2012) menulis dapat membantu peserta didik untuk mengekspresikan pengetahuan dan gagasan mereka. peserta didik menuliskan hasil diskusi dan menjawab pertanyaan yang ada pada LKS. Selain itu pada tahap write ini, peserta didik membuat kesimpulan dan laporan dari hasil eksperimen. Tahap ini merupakan pengembangan dari model TTW.

f) Evaluation

Tahap Evaluation yaitu evaluasi terhadap pengetahuan, keterampilan dan perubahan proses berfikir peserta didik. Pada tahap ini peserta didik di evaluasi tentang materi gerak lurus berupa lisan maupun tulisan. Tahap ini merupakan pengembangan dari pendekatan konstruktivistik.

Tabel 1. Sintaks Pengembangan model POE2WE

\begin{tabular}{|c|c|c|c|}
\hline No. & $\begin{array}{l}\text { Sintaks POEW } \\
(\text { Samosir, 2010) }\end{array}$ & $\begin{array}{c}\text { Sintaks Model } \\
\text { Pembelajaran dengan } \\
\text { Pendekatan }\end{array}$ & $\begin{array}{l}\text { Model POE2WE (Nana et al., } \\
\text { 2014) }\end{array}$ \\
\hline & & $\begin{array}{l}\text { Kontruktivistik (Duffy } \\
\text { dan Junassen, 1992) }\end{array}$ & \\
\hline 1. & $\begin{array}{l}\text { (Prediction) } \\
\text { membuat prediksi, } \\
\text { membuat dugaan. }\end{array}$ & $\begin{array}{l}\text { (Engagement) } \\
\text { pendahuluan } \\
\text { membuat pertanyaan } \\
\text { menggali pengetahuan } \\
\text { awal peserta didik. }\end{array}$ & $\begin{array}{l}\text { (Prediction) } \\
\text { Membuat dugaan atau prediksi. } \\
\text { Tahap Engagement identik } \\
\text { dengan Predict pada POEW }\end{array}$ \\
\hline 2. & $\begin{array}{l}\text { (Observation) } \\
\text { Melakukan } \\
\text { penelitian, } \\
\text { pengamatan }\end{array}$ & $\begin{array}{l}\text { (Exploration) menguji } \\
\text { prediksi ,melakukan dan } \\
\text { mencatat hasil } \\
\text { pengamatan. }\end{array}$ & $\begin{array}{l}\text { (Observation) Melakukan } \\
\text { observasi/pengamatan Tahap } \\
\text { Exploration identik dengan tahap } \\
\text { observation pada POEW. }\end{array}$ \\
\hline 3. & $\begin{array}{l}\text { (Explanation) Yaitu } \\
\text { memberi penjelasan }\end{array}$ & $\begin{array}{l}\text { (Explation) menjelaskan } \\
\text { konsep dengan kalimat } \\
\text { mereka sendiri }\end{array}$ & $\begin{array}{l}\text { (Explanation) Menjelaskan Pada } \\
\text { tahap explanation identik dengan } \\
\text { explation pada pendekatan } \\
\text { konstruktivistik }\end{array}$ \\
\hline 4. & $\begin{array}{l}\text { (Write) Membuat } \\
\text { kesimpulan }\end{array}$ & $\begin{array}{l}\text { (Elaboration) Aplikasi } \\
\text { konsep dalam kehidupan } \\
\text { sehari-hari. }\end{array}$ & $\begin{array}{l}\text { (Elaboration) Aplikasi konsep } \\
\text { dalam kehidupan sehari-hari } \\
\text { merupakan pengembangan dari } \\
\text { pendekatan Konstruktivistik }\end{array}$ \\
\hline
\end{tabular}




\begin{tabular}{|l|l|l|l|}
\hline 5. & $\begin{array}{l}\text { (Evaluation) Evaluasi } \\
\text { terhadap pengetahuan, } \\
\text { keterampilan dan } \\
\text { perubahan proses berfikir } \\
\text { peserta didik. }\end{array}$ & $\begin{array}{l}\text { (Write) Menuliskan hasil diskusi } \\
\text { sebagai kesimpulan. Merupakan } \\
\text { pengembangan dari model POEW }\end{array}$ \\
\hline $\mathbf{6 .}$ & & $\begin{array}{l}\text { (Evaluation) Evaluasi terhadap } \\
\text { efektifitas fase-fase sebelumnya. } \\
\text { Merupakan pengembangan dari } \\
\text { pendekatan Konstruktivistik }\end{array}$ \\
\hline
\end{tabular}

Sumber: Nana, Surahman E. 2019. Pengembangan Inovasi Pembelajaran Digital Menggunakan Model Blended POE2WE di Era Revolusi Industri 4.0. Prosiding SNFA (Seminar Nasional dan Aplikasinya), 82-90.

Tabel 2. Kegiatan Model Pembelajaran Model POE2WE

\begin{tabular}{|c|c|c|}
\hline Fase-fase & Kegiatan Guru & Kegiatan Peserta \\
\hline Prediction & $\begin{array}{ll}\text { - } & \begin{array}{l}\text { Menyampaikan tujuan } \\
\text { pembelajaran. }\end{array} \\
\text { - } & \text { Mengajukan pertanyaan } \\
\text { kepada siswa } \\
\text { - } \\
\text { Menginventarisir prediksi dan } \\
\text { alasan yang di kemukakan peserta } \\
\text { didik }\end{array}$ & $\begin{array}{ll}\text { - } & \text { Memperhatikan penjelasan dari } \\
\text { - } & \text { Muru. } \\
\text { Memprediksi jawaban } \\
\text { - } \\
\text { pertanyaan dari guru } \\
\text { Mendiskusikan hasil } \\
\text { prediksinya }\end{array}$ \\
\hline Observation & 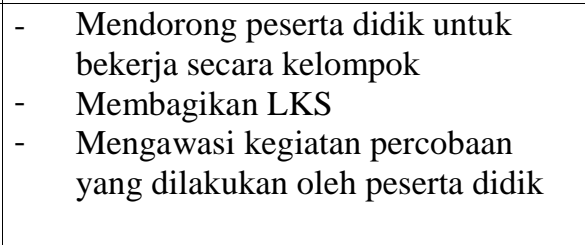 & $\begin{array}{ll}- & \text { Membentuk kelompok } \\
\text { - } & \text { Melakukan percobaan } \\
\text { - } & \text { Mengumpulkan data hasil } \\
& \text { percobaan } \\
\text { - } & \text { Melakukan diskusi kelompok } \\
\text { - } & \text { Menyimpulkan hasil percobaan }\end{array}$ \\
\hline \multirow[t]{2}{*}{ Explanation } & $\begin{array}{ll}- & \text { Mendorong peserta didik untuk } \\
\text { - } & \text { menjelaskan hasil percobaan. } \\
& \text { Meminta peserta didik } \\
\text { pempresentasikan hasil } \\
\text { percobaannya } \\
\text { - } & \text { Mengklarifikasikan hasil } \\
\text { - } & \text { percobaannya } \\
& \text { Menjelaskan konsep/definisi baru }\end{array}$ & $\begin{array}{ll}- & \text { Mengemukakan pendapatnya } \\
\text { tentang hasil percobaan } \\
\text { - } & \text { Mengemukakan pendapatnya } \\
& \text { tentang gagasan baru } \\
& \text { berdasarkan hasil percobaan. } \\
\text { - } & \text { Menanggapi presentasi dari } \\
& \text { kelompok lain. }\end{array}$ \\
\hline & & \begin{tabular}{|l}
- \\
Konsep baru dari guru dapat di \\
terima
\end{tabular} \\
\hline Elaboration & $\begin{array}{l}\text { Memberi permasalahan berkaitan } \\
\text { dengan penerapan konsep. } \\
\text { Mendorong peserta didik untuk } \\
\begin{array}{l}\text { menerapkan konsep baru dalam } \\
\text { situasi baru }\end{array}\end{array}$ & $\begin{array}{l}\text { - Menerapkan konsep baru dalam } \\
\text { situasi baru atau kehidupan } \\
\text { sehari-hari. }\end{array}$ \\
\hline Write & $\begin{array}{l}\text { - Memberi kesempatan kepada peserta } \\
\text { didik untuk mencatat hasil diskusi } \\
\text { serta kesimpulan. }\end{array}$ & $\begin{array}{l}\text { - Mencatat hasil penjelasan dan } \\
\text { kesimpulan dari guru dan } \\
\text { diskusi kelompok }\end{array}$ \\
\hline Evaluation & $\begin{array}{l}\text { Mengajukan pertanyaan untuk } \\
\text { penilaian proses } \\
\text { Menilai pengetahuan peserta didik } \\
\text { Memberikan balikan terhadap } \\
\text { jawaban peserta didik }\end{array}$ & $\begin{array}{l}\text { Menjawab pertanyaan } \\
\text { berdasarkan data } \\
\text { Mendemonstrasikan kemampuan } \\
\text { dalam penguasaan konsep }\end{array}$ \\
\hline
\end{tabular}


Sumber: Nana, Surahman E. 2019. Pengembangan Inovasi Pembelajaran Digital Menggunakan Model Blended POE2WE di Era Revolusi Industri 4.0. Prosiding SNFA (Seminar Nasional dan Aplikasinya), 82-90.

\subsection{TERMODINAMIKA}

Termodinamika adalah cabang ilmu Fisika yang membahas tentang hubungan antara panas (kalor) dan usaha yang dilakukan oleh kalor tersebut. Dalam subpokok termodinamaika membahas tentang system, pembatas, lingkungan. System dalam termodinamika dibagi menjadi tiga macam

1. System terbuka terjadi apabila ada pertukaran massa dan energy system dengan lingkungannya.

Contohya tumbuh-tumbuhan

2. System tertutup terjadi apabila ada pertukaran energy tetapi tidak terjadi pertukaran massa system dengan lingkungannya. Misalnya green house

3. System terisolasi tidak ada pertukaran massa da energy system dengan lingkungan misalnnya tabung gas yang terisolasi

Selain membahas system dengan lingkungannya dalam termodinamika juga membahas hukumhukum termodinamika yaitu hukum 1 termodinamika, hukum 2 termodinamika dan hukum 3 termodinamika.

Hukum 1 termodinamika menyatakan tentang kekealan energi dalam sistem. Hukum 1 termodinamika berbunyi “ jumlah energi yang diberikan pada sistem sama dengan perubahan energi dalam sistem ditambah usaha yang dilakukannya.

Secara matematis : $\quad Q=\Delta U+W$

Dimana $\mathrm{Q}$ sebagai kalor yang diterima atau dilepaskan sistem, $\Delta U$ perubahan energy dalam sistem dan W usaha yang dilakukan sistem. Hukum 1 termodinamika dapat diterapakan pada proses isokhorik, isothermal, isovolum, adiabatic.

Hukum 2 termodinamaika memberi batasan terhadap perubahan energy yang dapat berlangsung atau tidak dapat berlangsung. Dan menyatakan arah reaksi sistem. Hukum 2 termodinamika juga membahas tentang entropi. Entropi adalah suatu ukuran banyaknya kalor yang tidak dapat diubah menjadi usaha. Secara matematis dirumuskan

$$
\Delta S=\frac{Q}{T}
$$

Penerapaan hukum 2 termodinamika dalam kehidupan sehari-hari diterapakan dalam mesin kalor (mesin carnot) dan mesin pendingin (revrigator). Mesin kalor mengubah energy termal menjadi usaha dengan cara memindahkan kalor dari reservoir bersuhu tinggi ke reservoir bersuhu rendah. Sedangkan mesin pendingin kebalikan dari mesin carnot (kalor), memerlukan usaha untuk memindahkan kalor dari reservoir bersuhu rendah ke reservoir bersuhu tinggi.

\subsection{PhET}

Physics Education Technologi ( $\mathrm{PhET}$ ) adalah progam animasi yang dapat digunakan dalam proses pembelajaraan fisika. PhET didisain khusus oleh para ahli dengan tujuan memberikan kemudahan kepada para pendidik fisika dalam menyampaikan materi pembelajaran. Selain bertujuan untuk memudahkan guru fiisika dalam penyampaikan materi, $\mathrm{PhET}$ juga berfungsi untuk memudahkan peserta didik memahami materi khusus nya materi-materi yang berkaitan dengan alam nyata dan perlu 
dipraktekkan di laboratoriium, seperti pegas, cermin dan bayangan ,suhu kalor, teori kinetic gas dan lainlain. (Bizar Al Furqan,et al,2019)

Menurut Wieman,(2010) PhET memberi kemudahan kepada pendidik untuk menghindari percoban berat yang memerlukan alat-alat yang serba mahal dan sulit untuk di dapatkan, PhET juga memberi kemudahan karna hanya menggunakan komputer/laptop sebagai alat utama yng digunakan dengan menggunakan master program utama adalah PhET itu sendiri. Setelah memahami PhET, diharapkan : a.Peserta didik dapat belajar dengan menyenangkan dan juga dapat memahami materi dengan baik; $b$. Penerapan PhET di dalam kelas diharapkan menjadi materi bagi pendidik dan peserta didik sebelum melakukan praktikum, dan PhET juga diharapkan dapat menjadi percobaan/eksperimen alternative bagi sekolah-sekolah yang kurang atau tidak memiliki alat untuk praktikum. (Bizar Al Furqan et al,2019)

Kelebihan dalam penggunaan PhET dibandingkan dengan menggunakan peralatan dalam demonstrasi (Wieman dkk. 2010: 226) :

a. Dapat digunakan dikelas ketika peralatan laboratorium tidak tersedia atau sulit untuk dirangkai;

b. Dapat digunakan untuk melakukan eksperimen yang tidak mungkin untuk dilakukan;

c. Mudah untuk mengubah variabel-variabelnya;

d. Dapat menampilkan hal-hal yang tidak dapat dilihat;

e. Peserta didik dapat menjalankan simulasi tersebut menggunakan komputernya sendiri di rumah untuk mengulangi atau memperdalam pemahamannya mengenai eksperimen di kelas.

\subsection{Penggunaan Model POE2WE dalam Pembelajaran Fisika Materi Termodinamika dengan Bantuan PhET (Physics Education Technology) Simlation}

Materi subyek termodinamika merupakan salah satu materi fisika yang banyak memiliki konsepkonsep abstrak, sulit untuk divisualisasikan dan memiliki kompleksitas yang cukup tinggi. Biasanya, pembelajaran ini dilakukan secara konvensional yakni mengembangkan model matematika abstraks dan prinsip fisika dengan grafik dua dimensi dan teks saja, kemudian menggunakannya untuk memecahkan suatu permasalahan secara praktis. Model pembelajaran ini dapat mengakibatkan suatu situasi dimana siswa tidak dapat menerapkan teori yang telah dipelajarinya ke dalam situasi nyata, atau tidak dapat menjelaskan dengan pengetahuan yang telah diperolehnya. (Jamuri ,dkk, 2015).

Model POE2WE adalah salah satu solusi kreatif dengan pendekatan konstrutivis yang dianggap memiliki efek pada kreativitas peserta didik di masa depan . Model POE2WE membagun pengetahuan dengan urutan proses dimulai dari meramalkan atau memprediksi suatu solusi untuk memecahkan masalah. Pemecahan masalah dan membuktikan prediksi dengan melakukan eksperimen. Kemudian menjelaskan hasil eksperimen yang diperoleh secara lisan maupun tulisan. Kemudian diaplikasikan penerapannya dalam kehidupan sehari-hari. Hasil dari diskusi dituliskan dalam bentuk catatan dan membuat evaluasi tentang pemahamn peserta didik baik secara lisan maupun tertulis (Nana et al, 2014; 2016)

Model pembelajaran POE2WE dapat menjadikan peserta didik sebagai subjek di dalam pembelajaran. peserta didik secara aktif menemukan suatu konsep melalui pengamatan atau eksperimen. (Nana, E Surahman,2019). Eksperimen yang dilakukan dapat berupa eksperimen real ataupun eksperimen virtual. Eksperimen virtual memanfaatkan computer untuk menyimlasikan sesuatu yang rumit ataupun abstrak seperti konsep-konsep termodinamika. Materi termodinamika ketika melakukan eksperimen real memerlukan alat dan bahan yang memadai dan biaya cukup mahal. Oleh karena itu penulis mencoba menggunakan eksperimen virtual dengan menggunakan PhET Simulation untuk pemahaman pada konsep termodinamika.

PhET berfungsi untuk memudahkan peserta didik memahami materi khusus nya materi-materi yang berkaitan dengan alam nyata dan perlu dipraktekkan di laboratoriium Dengan menggunakan PhET peserta didik dapat memvisualisaikan dan berinteraksi dengan fenomena yang akan merka alami jika melakukan eksperimen real. Dan peserta didik akan lebih faham ketika diberi pemahaman dengan 
eksperimen. Peserta didik akan tahu bagaimana terjadinya atau memahami konsep-konsep yang muncul dari fenomena fiska tersebut.

\section{PENUTUP}

Dari beragai pembahasan yang telah diuraikan, kesimpulan yang dapat ditarik bahwa model pembelajaran POE2WE dapat diterapkan dalam pembahasan materi termodinamika dengan bantuan PhET sebagai alternatif eksperimen real menjadi ekperimen virtual.

\section{UCAPAN TERIMA KASIH}

Terima kasih kepada bapak Dr.Nana M.Pd. selaku dosen pengampu Fisika Sekolah 2 dan semuannya yang telah membantu demi kesempurnaan artikel ini menjadi lebih baik.

\section{Daftar Pustaka}

Al Furqan, Bizar, dkk(2019). Pengaruh Model Problem Based Learning (PBL) Berbantuan Media Animasi Terhadap Hasil Belajar Fisika Peserta Didik Pada Materi Termodinamika dan Gelombang Mekanik Kelas XI MAN 2 PADANG. Pillar of Physics Education, Vol 12. No 4, 2019, 697-704. Dipetik Februari 17,2020

Fathul Mubarok, M. (2014). Penerapan Pembelajaran Fisika pada Materi Cahaya dengan Media PhET Simulations untuk Meningkatkan Pemahaman Konsep Siswa di SMP. Jurnal Inovasi Pendidikan Fisika, III(1), 76-80. Dipetik Februari 17, 2020

Jamuri, Kosim, Aris Doyan (2015, Januari). Pengaruh Model Pembelajarnan Kooperatif Stad Berbasis Multi Media Interaktif Terhadap Penguasaan Konsep Siswa pada Materi Termodinamika. Jurnal Penelitian Pendidikan IPA (JPPIPA), Vol 1, No 1 (2015). Dipetik Februari 17,2020

Nana, Sajidan, Akhyar, M., \& Rochsantiningsih, D.. Pengembangan Pembelajaran Fisika SMA Melalui Elaboration Write dan Evaluation (EWE) dalam Kurikulum 2013.

Nana. (2018, Oktober 27). Implementasi Model POE2WE dengan Pendekatan Saintifik dalam Pembelajaran Gerak Lurus di SMA. Seminar Nasional Pendidikan Sains, 18. Dipetik Februari 17, 2020

Nana, Sajidan, Akhyar, M., \& Rochsatiningsih, D. (2014). The development of Predict, Observe, Explain, Elaborate, Write, and Evaluate (POE2WE) Learning Model in Physics Learning at Senior Secondary School. Journal of Education and Practice, 5(19), 56-65

Nana, Rochsanriningsih, D., Akhyar, M., \& Sajidan. (2016). The Effectiveness of Scientific Approach Through Predict, Observe, Explain, Elaborate, Write and Evaluate (POE2WE) Model on the Topic of Kinematics (Rectilinear Motion) at Senior High School. The Social Sciences, 11(6), 1028-1034.

Nana dan Surahman E. (2020). POE2WE Model as an Alternative for Learning Physics in Industrial Revolution 4.0 Era. Advances in Social Science, Education and Humanities Research, 397(2), 10131022 
Nana, Surahman E. (2019). Pengembangan Inovasi Pembelajaran Digital Menggunakan Model Blended POE2WE di Era Revolusi Industri 4.0. Prosiding SNFA (Seminar Nasional dan Aplikasinya), 8290 .

Wieman, C.E dkk. (2010). Teaching physics using PhET simulations. The Physics Teacher. Vol 48:225-227 